\title{
The 'Vida' of Queen Fredegund in 'Tote Listoire de France': vernacular translation and genre in thirteenth-century French and Occitan literature
}

Article

Accepted Version

Leglu, C. (2017) The 'Vida' of Queen Fredegund in 'Tote Listoire de France': vernacular translation and genre in thirteenth-century French and Occitan literature. Nottingham French Studies, 56 (1). pp. 98-112. ISSN 0029-4586 doi: https://doi.org/10.3366/nfs.2017.0170 Available at https://centaur.reading.ac.uk/39405/

It is advisable to refer to the publisher's version if you intend to cite from the work. See Guidance on citing.

Published version at: http://www.euppublishing.com/journal/nfs

To link to this article DOI: http://dx.doi.org/10.3366/nfs.2017.0170

Publisher: Edinburgh University Press

All outputs in CentAUR are protected by Intellectual Property Rights law, including copyright law. Copyright and IPR is retained by the creators or other copyright holders. Terms and conditions for use of this material are defined in the End User Agreement. 


\section{CentAUR}

Central Archive at the University of Reading

Reading's research outputs online 
THE VIDA OF QUEEN FREDEGUND IN TOTE LISTOIRE DE FRANCE:

\section{VERNACULAR TRANSLATION AND GENRE IN THIRTEENTH-CENTURY \\ FRENCH AND OCCITAN LITERATURE.}

\section{Catherine Léglu.}

The emergence of vernacular prose literature is a feature of the early thirteenth century both in Northern French and in Occitan. This article analyses the translation of an early-medieval chronicle into a language that combines Old French and Occitan, with a view to furthering the understanding of the importance of translation to the development of medieval vernacular literary and historical writing. ${ }^{1}$

Medieval French literature of the twelfth to fifteenth centuries is replete with what McCracken has termed 'the romance of adultery', tales in which queens betray their husbands and concomitantly commit treason against their king. McCracken argues that these tales (most famously, those of Guenevere and Iseut) are particularly concerned with associating the king's lack of control over his spouse with his loss of authority over his realm. ${ }^{2}$ These stories also chime with the no less popular 'narratives of accused queens', whose heroines are innocent. Proving the innocence of the queen is a means of restoring dynastic order by placing the king's legitimate heir on the throne. The historical evidence for such scandals was

\footnotetext{
${ }^{1}$ See Catherine Léglu, “Just as Fragments are Part of a Vessel”: A Translation into Medieval Occitan of the Life of Alexander the Great', in Medieval Translation, ed. by Christa Canitz (Florilegium, forthcoming 2017), and also by Léglu, 'The Devil's Daughters and the Question of Translation between Occitan and Anglo-Norman French: De las .vii. filhas del dyable (British Library Add. MS 17920)', La France Latine (forthcoming). My thanks to Irène Fabry-Tehranchi, Françoise Le Saux and two anonymous peer reviewers for their comments and suggestions on an early draft of this article.

${ }^{2}$ Peggy McCracken, The Romance of Adultery: Queenship and Sexual Transgression in Old French Literature (Philadelphia, PA: University of Pennsylvania Press, 1998), pp.15-24, 5283.
} 
limited to the Carolingian era, until the crises of succession to the throne of France that led to the rise of the Valois lineage and the exclusion of women from royal succession in the early fourteenth century. ${ }^{3}$

Meanwhile, medieval Occitan literature of the same era features many adulterous aristocratic women who do not suffer accusation. In troubadour vidas and razos, love triangles between the poet, the lady and her husband are occasionally violent but never lead to formal, legal punishment. ${ }^{4}$ Adultery was no more condoned in Occitan-speaking regions than further north, but it has been argued recently by Otis-Cour that legal codes issued to deal with cases of adultery were comparatively lenient. ${ }^{5}$ There is a difference between the treatment of ordinary wives and that of women in prominent political positions for whom adultery equated with treason, but it is striking that in Otis-Cour's account, much confessional and secular legislation (especially in Southern France) suggests that displaying contrition, paying fines or even running away sufficed to erase an accusation. ${ }^{6}$ The lack of 'adulterous' and 'accused' queens in Occitan literature may indicate a cultural difference.

It is interesting, therefore, to examine a translation into a hybrid French-Occitan vernacular of a narrative in which an adulterous and regicidal queen who is also a mother

\footnotetext{
${ }^{3}$ Nancy B. Black, Medieval Narratives of Accused Queens (Gainesville: University of Florida Press, 2003), pp.6-9, 68-71. Geneviève Bührer-Thierry, 'La reine adultère', Cahiers de civilisation médiévale, 35 (1992), 299-312, and Sabine Savoye, 'Le pouvoir des reines mérovingiennes dans l'hagiographie mérovingienne', in Femmes de pouvoir et pouvoirs de femmes, dans l'Europe occidentale médiévale et moderne, ed. by E. Santinelli and A. Nayt Dubois (Valenciennes: Presses Universitaires de Valenciennes, 2009), pp.43-60.

${ }^{4}$ Daniel Lacroix, Les amours du poète: Poésie et biographie dans la littérature du XIII ${ }^{e}$ siècle (Geneva: Slatkine, 2004), pp.45-62; Simon Gaunt, Love and Death in Medieval French and Occitan Courtly Literature: Martyrs to Love (Oxford: Oxford University Press, 2006), pp.73-103 (pp.77-9).

${ }^{5}$ Ruth Mazo Karras, Sexuality in Medieval Europe: Doing unto Others, $2^{\text {nd }}$ edn (Abingdon: Routledge, 2012), pp.112-22. Mary Jane Schenk, 'Reflections on the Costuma d'Agen', Tenso, 26.1-2 (2011), 16-29 (pp.26-7), and Leah Otis-Cour, "De jure novo": Dealing with Adultery in the Fifteenth-Century Toulousain', Speculum, 84 (2009), 347-92 (pp.352-4, n.24).

${ }^{6}$ Otis-Cour, “"De jure novo"”, p.349.
} 
emerges triumphant. It sits within a chronicle of the kings of France, composed either in the early or the mid-thirteenth century, entitled Tote listoire de France. ${ }^{7}$ It was copied in the Saintonge, in a context that also produced the first identified author of troubadour vidas and razos, Uc de Saint-Circ, who composed for the Saintongeais nobleman, Savaric de Mauléon (d.1233). Tote listoire's patrons are unknown. ${ }^{8}$ The text emerges in a context where French and Occitan were competing for both political and literary supremacy as the languages of French (Capetian), English (Plantagenet) and local rulers. This article does not attempt to identify specific political tensions in this region; rather it will focus on the generic and literary identity of this text.

The chronicle's life of Queen Fredegund of Neustria (d. 597) is translated from the eighth-century Liber historiae francorum (hereafter LHF). ${ }^{9}$ The subject of lurid writings from Gregory of Tours to the modern era, Fredegund does not make many appearances in medieval vernacular literature. Christine de Pizan recast her bloodthirstiness as valour at a time when she was evoked cautiously as a woman who had worked to maintain the stability

\footnotetext{
${ }^{7}$ Tote l'Istoire de France (Chronique saintongeaise), ed. by F. W. Bourdillon (London: Nutt, 1897).

${ }^{8}$ Henry J. Chaytor, Savaric de Mauléon, Baron and Troubadour (Cambridge: Cambridge University Press, 1939), William E. Burgwinkle, Love for Sale: Materialist Readings of the Troubadour Razo Corpus (New York: Garland, 1997), pp.107-12, Saverio Guida, Primi approcci a Uc de Saint-Circ (Soveria Mannelli : Rubbettino, 1996), Martine Cao Carmichael de Baiglie, 'Savary de Mauléon (ca 1180-1233), chevalier-troubadour poitevin : traîtrise et société aristocratique', Le Moyen Age, 105 (1999), 269-305, Catherine Léglu, 'Savaric de Mauléon: entre vidas et biographie', in Le Rayonnement de la civilisation occitane à l'aube d'un nouveau millénaire, sixième congrès international de l'Association Internationale d'Études Occitanes, 12-19 septembre 1999, ed. by G. Kremnitz, B. Czernilofsky, P. Cichon, R. Tanzmeister (Vienna: Praesens, 2001), pp.458-63.

${ }^{9}$ Liber Francorum Historiae, ed. by Bruno Krusch, Monumenta Germaniae Historia, Scriptores rerum Merovingicarum, vol. II (Hanover: Hahn, 1888), pp.215-328. Online: < http://www.dmgh.de/de/fs1/object/display/bsb00000749_meta:titlePage.html?text=true\&sort $=$ score \&order=desc\&divisionTitle $\_s t r=\& h l=$ false \&fulltext=liber+francorum+historiae\&sortI ndex=010:020:0002:010:00:00\&context=liber\%20francorum\%20historiae $>$ [accessed 25 February 2015]. I have consulted but not followed the quite different translation in Liber Historiae Francorum: Le Livre de l'Histoire des Francs depuis leurs origines jusqu'à 721, transl. by Nathalie Desgrugillers-Billard, (Clermont-Ferrand: Editions paleo, 2007), ch.35, pp.122-4, Latin text, pp.222-4.
} 
of her husband's royal line. Fredegund is said to have started life as a serving-woman to Audovera, queen to King Chilperic I (c. 539-84). She seduced the king and persuaded him to repudiate Audovera, but she gained the throne only by strangling Chilperic's next wife, Galswintha. After Chilperic's murder in the year 584, Fredegund succeeded in maintaining her son Clothar II on the throne only with the support of her brother-in-law Guntram (whom she is also said to have tried to kill). ${ }^{10}$ Tote listoire narrates Fredegund's many crimes without comment, up to her murder of her husband:

Text:

Fredegundis estet molt bela reina, e engigniosa e avostressa. Landerix estet molt adonques prisez en la cite lo rei, le quau la reina amot molt de luxuriosa amor. Un ior quant li reis ala chaicer qui amot molt Fredegunda, s'en torna e trova la son chep lavant en la chanbra, si la ferit ob un fust sor les nages. ${ }^{11}$ Ela cuida que fust Landericx e dist, "Porque faiz tu co Landeric ?" mas ela reguardans sus vist lo rei e ot grant paor. Li reis molt tristes ala chaicer. La reina apela Landeric. Si li reconta co que li reis li avoit fait. Si li dist : "Pensa que feras, quar demain serom liure a torment." Il dist enplorant, "Ie no sai que ie fazce." Ela li dist, "Naies paor. Oies mon conseil e no murrum. Quant li reis vendra aus vespres de chaicer, ie sai bien que ferai. Enveion qui l'ocie e criant les cries que li aguais Hildebert l'a mort. ${ }^{12}$ Nos regnerom apres e mis filz." Quant li reis vint de chaicer auques nuit, dui ioenceu iogleor

${ }^{10}$ Christine de Pizan, La Cité des Dames, cf. La Città delle Donne, ed. by Earl Jeffrey Richards, transl. by Patrizia Caraffi (Milano : Luni Editrice, 1997), ch.XXXIV. Colette Beaune, 'La mauvaise reine des origines. Frédégonde aux $\mathrm{XIV}^{\mathrm{e}}$ et $\mathrm{XV}^{\mathrm{e}}$ siècles', Mélanges de l'école française de Rome, Italie et Méditerranée, 113 (2001), 29-44, Éliane Viennot, 'L'histoire des reines de France dans le débat sur la loi salique, $X V^{\mathrm{e}}-\mathrm{XVI}^{\mathrm{e}}$ siècles', in Femmes de pouvoir et pouvoirs de femmes, pp.83-95.

${ }^{11}$ Emil Levy, Petit Dictionnaire provençal-français (Heidelberg : Carl WinterUniversitätsverlag, 1973), p.256 cites the feminine plural noun 'naches, nagas' meaning 'buttocks'. 5005B reads 'par desus les espaules', Bourdillon, p.38, see n.34 below. ${ }^{12}$ This differs from Krusch, 'mittamus qui eum interficiat, et proclament, quod Childebertus rex Auster insidiatus ei fuisset', p.303. Aguais seems to correspond to Old Occitan noun agach, 'guet, aguet, embûche', Levy, p.10. 
envoie de Fredegunt, dementra // quil descendi del chivau e les persones s'en furent alees, ils le ferirent ot les costeus par lo ventra. Il crianz mori. Cil qui l'ocesirent criarent e distrent que li aguais Hildebert l'aveit mort, ${ }^{13}$ adonques l'oz corrut ca e la, e ne trova rien si s'en retorna. Nallufus qui estoit evesques le seveli en l'iglise saint Vincent a Paris. E regna .xxx. et .iii. anz. Fredegundis tenoit lo regne ot Clotaira son petit fil e Landerix ensenbla quavoit esleu au plus aut deu palais. Li franceis si estabblirent Clodomira petit reis sor eus. ${ }^{14}$

Translation:

Fredegund was a very beautiful queen, cunning and adulterous. Landeric, whom the queen loved with great lust, was at that time most highly valued in the king's city. One day, when the king (who loved Fredegund a great deal) set out hunting, he turned back, found her washing her hair in the chamber, and hit her on the buttocks with a stick. She thought that he was Landeric and said, "Why are you doing that, Landeric?" But looking up, she was that it was the king, and she took fright. The king, feeling very sad, went hunting. The queen summoned Landeric. She told him what the king had done. She said to him, "Think of something to do, because tomorrow we will be given over to be tortured." He said, weeping, "I do not know what to do." She said, "Do not be afraid. Listen to my advice and we shall not die. When the king returns at Vespers from hunting, I know what to do. Let's send someone to kill him, and let there be raised a hue and cry that Childebert's men killed him in an ambush. Then we shall reign with my son." When the king came back from the hunt after nightfall, two young minstrels were sent by Fredegund. When he dismounted from his horse and his people had dispersed, they stabbed him in the belly with knives. Yelling, he died. Those who killed him shouted it about that Childebert's men had killed him in an ambush;

\footnotetext{
${ }^{13}$ Once more, the aguais are not in keeping with the version edited by Krusch and translated by Desgrugillers-Billard, where the blame is put on Childebert II, king of Austrasia.

${ }^{14}$ Krusch, LHF, pp.302-04. Paris BnF fr. 5714, fols $18^{\mathrm{r}}-18^{\mathrm{v}}$, Bourdillon, pp.38-39. Microfilm online: 〈 http://gallica.bnf.fr/ark:/12148/btv1b9009467n.r=turpin+\%28pseudo-\%29.langEN> [accessed 25 February 2015].
} 
then the army ran here and there but found nothing, and came back. Mallulfus, who was then bishop, had him buried in the church of Saint Vincent in Paris. He had reigned thirty-three years. Fredegund took the throne with her youngest son Clothar, together with Landeric, for she had elected him to the highest office in the palace. The Franks set up Clodomir as petty king under them.

Tote listoire de France, 'a wonderful and woeful work' according to its editor, was probably composed to complement an interpolated translation of the Pseudo-Turpin Chronicle. ${ }^{15}$ It lists and narrates many religious foundations in the western regions of Guyenne and Aquitaine, which appear subsequently in interpolations of the Ps-Turpin. Much of the post-Merovingian part of the text derives from the chronicles of Ademar of Chabannes (d.1034), who worked and wrote both in Angoulême and at the abbey of Saint Martial-deLimoges. ${ }^{16}$ Tote listoire de France survives in two manuscripts and may have been originally associated with a third:

MS Paris BNF fr. 5714 (c. 1260):

Tote listoire de France (ff.1-40v), Pseudo-Turpin Chronicle (ff.41- 89)

${ }^{15}$ Bourdillon, pp.xix, 6-7. André de Mandach, Naissance et développement de la chanson de geste en Europe : I. La Geste de Charlemagne et de Roland (Geneva - Paris: Droz - Minard, 1961), pp.79-81. Historia Karoli Magni et Rotholandi, ou Chronique du Pseudo-Turpin, ed. Cyril Meredith-Jones (Geneva: Droz, 1936). Also by André de Mandach, Chronique dite Saintongeaise, texte franco-occitan inédit "Lee". À la découverte d'une chronique gasconne du XIII siècle et de sa poitevinisation (Tübingen: Niemeyer, 1970).

${ }^{16}$ Bourdillon, pp.xxvii, xxxi-xxxiv; Etienne Darley, Fragments d'anciennes chroniques d'Aquitaine d'après des manuscrits du XIII siècle, introduction et texte (Bordeaux : Féret et fils, 1906), pp.21, 22. Claude Buridant, 'La traduction de la chronique d'Adémar de Chabannes dans Tote l'istoire de France', Revue de linguistique romane, 40 (1976), 57-115 (pp.57-9). 
Aberystwyth, NLW, ms 5005B (formerly known as the 'Lee' MS) (c.1250-1300): ${ }^{17}$

Tote listoire de France (pp.1-67, lacks first quire), Pseudo-Turpin Chronicle (pp. 68-158)

MS Paris BNF fr. 124 (c.1320-40):

Pseudo-Turpin Chronicle in Occitan (ff.1-12v), Pseudo-Turpin Chronicle in Latin (ff.13-21).

Table 1: The manuscript tradition of Tote listoire de France. ${ }^{18}$

While the content of the two surviving copies is near-identical (5005B is slightly longer), they exhibit marked differences in spelling and to a lesser extent in lexis, indicating that fr. 5714 was copied by a scribe whose French had more Occitan interference than 5005B:

Fredegundis estet molt bela reina, e engigniosa e avostressa. Landerix estet molt adonques prisez en la cite lo rei, le quau la reina amot molt de luxuriosa amor. (fr. 5714, fol.18, col.1)

Fredegunde esteit molt bele roine, e engignose. e auostresse. Landerix si esteit a cel tens molt prisez en la cort lo roi. Lo quel la roine amot molt. de luxuriose amor. (Bourdillon, p.38, from 5005B).

The two texts diverge in the same way from their source. In this example, both omit the description of Landeric as 'the mayor of the palace, a clever and helpful man':

\footnotetext{
${ }^{17}$ The manuscript is paginated. My thanks to Caronwen Samuel at the National Library of Wales for this information.

${ }^{18}$ Microfilms of fr. 5714 and fr. 124 are online: < http://gallica.bnf.fr/?lang=EN> [accessed 25 February 2015].
} 
Erat autem Fredegundis regina pulchra et ingeniosa nimis atque adultera. Landericus quoque tunc maiorum domus palacii, uir ingeniosus ac utilis, quem memorata regina diligebat multum, quia in luxoria commiscebatur cum ea. (Krusch, p.302)

The Ps-Turpin in fr. 124 is the same as that which accompanies Tote listoire de France but shows signs of some corrections; it shares the stronger Occitan linguistic influence of fr.5714. ${ }^{19}$

The prologue to the Ps-Turpin states that it derives from a translation into French of a Latin Ps-Turpin bequeathed to Yolande, Countess of Saint-Pol by her brother Count Baudouin de Hainaut (d.1195). ${ }^{20}$ As a result, both it and Tote listoire de France have been treated as the earliest evidence of the circulation of the French Ps-Turpin, produced for a readership that had both linguistic and geographical ties with Saintonge and Poitou. The possible dating (c. 1200-60) places the texts in the period when the dialogue between the French and Occitan languages and literary traditions was strengthened by the dramatic changes wrought by the Albigensian crusade between 1209 and 1249, albeit in a region that was also caught between Capetian and Plantagenet control. ${ }^{21}$

Studies of the linguistic features of this trio of manuscripts have offered contradictory interpretations of their intended readership. French was used from the early thirteenth century in the Poitou and Saintonge as the language for charters and customaries, with strong

\footnotetext{
${ }^{19}$ Bourdillon, p.xvii. Cyril Meredith-Jones, 'The Chronicle of Turpin in Saintonge', Speculum, 13.2 (1938), 160-79 (p.161). On fr. 124, see de Mandach, Chronique dite Saintongeaise.

${ }^{20}$ Meredith-Jones, 'The Chronicle'.

${ }^{21}$ Elizabeth Aubrey, 'The Dialectic between Occitania and France in the Thirteenth Century', Early Music History, 16 (1997), 1-53.
} 
evidence of Occitan interference in scribal practice well into the fifteenth century. The same region hosted Occitan troubadours and translations from Latin into the French of the 'Poitevins'. ${ }^{22}$ Hybridisation between French and Occitan is also found in the manuscripts of the two chansons de geste Girart de Roussillon and Aigar et Maurin. ${ }^{23}$ Nadeau assigns 5005B and fr.5714 to Poitevin (c. 1250-1300), but the Ps-Turpin of fr. 124 to a mixture of Occitan, Poitevin and French (c.1320-40). ${ }^{24}$ In this, he departs from Pignon, who had concluded that Tote listoire might have been originally composed in Occitan, and Buridant, who seems to view it as mildly altered French. Nadeau cites but does not follow the hypothesis of de Mandach that both Tote listoire and the Ps-Turpin were an adaptation into 'une scripta franco-occitane très hybride' of a Gascon original. ${ }^{25}$ De Mandach's complex hypothesis remains unproven. The key factor for this enquiry is that texts written in these hybrid French - Occitan scripts are a feature of a linguistic zone that was truly mixed, and they were circulating in the courts of patrons of troubadour poetry in the early-to-mid thirteenth century.

The chief source of the Merovingian histories in Tote listoire, the Liber historiae francorum, is the third of the surviving chronicles of the Merovingian kings. ${ }^{26}$ Its

\footnotetext{
${ }^{22}$ Jacques Pignon, 'Les formes verbales de Tote l'istoire de France, texte saintongeais du XIII ${ }^{\mathrm{e}}$ siècle', Mélanges de linguistique offerts à Albert Dauzat par ses élèves et ses amis (Paris: Artrey, 1951), 257-74, and his L'évolution phonétique des parlers du Poitou (Vienne et Deux-Sèvres), 2 vols (Paris: Artrey, 1960), I, pp.39-57, 514-16, 522. 'Sic Aumericus, Pictave gentis amicus/ Eximie vitam Katherine transtulit istam', in La Passion de Sainte Catherine d'Alexandrie par Aumeric: Editée d'après le ms. 945 de la bibliothèque de Tours, ed. by Olivier Nadeau (Tübingen : Niemeyer, 1982), p.173.

${ }^{23}$ Mary W. Hackett, La langue de "Girart de Roussillon" (Geneva: Droz, 1970). Olivier Nadeau, 'Informations sur la langue de Aigar et Maurin', Romania, 115: 3-4 (1997), 337-67.

${ }^{24}$ Nadeau, La Passion de Sainte Catherine, pp.22-4.

${ }^{25}$ Pignon, 'Les formes linguistiques', Buridant, 'La traduction'. De Mandach, Chronique dite Saintongeaise, pp.24-45, and by the same author, 'À propos de la périphérie occitane: la Chronique dite saintongeaise, in Beiträge zur allgemeinen, indogermanischen und romanischen Sprachwissenschaft. Festschrift für Johannes Hubschmid zum 65. Geburstag (Bern - Munich: Francke, 1982), pp.867-97.

${ }^{26}$ Bourdillon, pp.38-9.
} 
predecessors are Gregory of Tours' Historia Francorum $(<590)$ and the chronicles attributed to Fredegar $(<642)$. The LHF was completed in 727 in Soissons by a Neustrian author (possibly a woman, according to McKitterick) who was keen to stress the actions of women, as well as to promote what $\mathrm{s} / \mathrm{he}$ perceived as an ideal balance of power between the Merovingian king and his Pippinid mayor of the palace. Although modern historians have tended to regard it as less reliable than its two predecessors, it was the most frequently copied of the three chronicles during the High Middle Ages (some fifty manuscripts survive). ${ }^{27}$ Pizarro's study of the narrative devices of early medieval historians has also drawn attention to the LHF as a well-crafted work. Pizarro concludes that the tendency to build narratives from anecdotes, creating a 'broken scene-to-scene rhythm', owes more to oral narrative than to classical models. He describes the LHF's narrative style as 'clumsy, childish prose', supporting an effective and vivid technique in which narrative proceeds as 'a chain of scenes', located firmly in time and space. ${ }^{28}$ Self-contained stories are presented with condensed dialogue and gesture, and objects introduced sparingly, to the point that (as will be discussed below) such texts appear to place gaps where the reader might expect explanations of motive or significance. ${ }^{29}$ These features are preserved in the thirteenth-century translation.

The LHF's particular interest in the political role of women is both shared and developed by Tote listoire. It preserves the long account of the life and deeds of Clovis's queen Clotilda, and adds the 'accused queen' legend of Charlemagne's mother, Berte. This section of Tote listoire is the earliest appearance of the tale, narrowly antedating Adenet le

\footnotetext{
${ }^{27}$ Richard A. Gerberding, The Rise of the Carolingians and the "Liber Historiae Francorum" (New York: Clarendon Press, 1989), by the same author, 'Paris, Bibliothèque Nationale latin 7906: An unnoticed very early fragment of the Liber Historiae Francorum', Traditio, 43 (1987), 381-386. Rosamund McKitterick, History and Memory in the Carolingian World (Cambridge: Cambridge University Press, 2004), p.10.

${ }^{28}$ Joaquín Martínez Pizarro, A Rhetoric of the Scene: Dramatic Narrative in the Early Middle Ages (Toronto, Buffalo, and London: University of Toronto Press, 1989), pp.9-14, quotations at pp.63-64, 14 and 41. On orality, see pp.53-6, 64, 75.

${ }^{29}$ Pizarro, Rhetoric of the Scene, pp.19-36, quotation at p.35.
} 
Roi's Berte aux grands pieds (c.1250).$^{30}$ The introduction of Berte means that Fredegund is placed between Clotilda and Charlemagne's mother: a transitional figure, Christian but preCarolingian in both her time and her mores, not subject to the same rules concerning adultery. ${ }^{31}$ McKitterick notes that the LHF author sought to affirm a vision of the ideal queen as 'a source of legitimacy for the royal line and... fount of Christian piety'. ${ }^{32}$ Fredegund might seem to be the antithesis to both these concerns, but in fact she preserves the legitimate line of succession, and maintains a firm grip on power as regent. There may even be a historicizing aspect to the narrative, because Savoye has suggested that Merovingian chronicles and saints' lives had no concept of the 'adulterous queen', with the LHF unique for its description of Fredegund as 'pulchra et ingeniosa nimis atque adultera' (beautiful, clever, and adulterous). ${ }^{33}$ In Tote listoire, Fredegund shares the intelligence and resourcefulness of both her predecessor Clotilda, and her successor Berte, but puts them to ends that are self-evidently of debatable moral value. It is therefore interesting to see that the LHF's lack of moralising comment on her actions is echoed in Tote listoire.

The translation changes only a few details of its source. Notably, the murderers are changed from a pair of drunken henchmen ('emissae homicidae inebriati a vino a Fredegunde') to two young minstrels ('dui ioenceu iogleor envoie de Fredegunt'). While their actions remain the same, the scene loses some of its sinister quality, arguably making the king's death less shameful. The most significant divergence from the source in one of the two manuscripts is the change of target for the king's stick in 5005B from Fredegund's buttocks

\footnotetext{
${ }^{30}$ Bourdillon, Tote listoire, pp.xxi-ii. Berte as grans piés, ed. Albert Henry (Geneva: Droz, 1982), pp.30-34, Black, Narratives, pp.68-71.

${ }^{31}$ Suzanne Fonay Wemple, Women in Frankish Society: Marriage and the Cloister, 500 to 900 (Philadelphia: University of Pennsylvania Press, 1981), pp.80-82. McCracken, Romance of Adultery, p.52, Bührer-Thierry, 'La reine adultère', Otis-Cour, "“de jure novo", p.351. ${ }^{32}$ McKitterick, History and Memory, p.13.

${ }^{33}$ Savoye, 'Les clerc mérovingiens n'établissent pas de corrélation directe entre l'inconduite sexuelle des reines et la débauche du pouvoir politique', 'Le pouvoir des reines', p.55.
} 
('in natibus suis', rendered correctly as 'nages' in fr. 5714) to her shoulders ('par desus les espaules'). ${ }^{34} 5005 \mathrm{~B}$ therefore appears to divert the reader's attention delicately away from Fredegund's fertile, adulterous body (its potential for producing illegitimate offspring), and focuses attention on the shoulders. In so doing, it may be that 5005B scribe subtly downplays Fredegund's crime, on the understanding that, to quote McCracken, 'the integrity of the queen's body symbolizes the integrity of the king's sovereignty'. ${ }^{35}$ By shifting the king's blow from gendered pelvis to un-gendered shoulders, the king's own authority is less affected by her inadvertent revelation of her association of such a touch with Landeric. As a result, the lovers' murder of him is an attack on a king whose prestige is less compromised than in the Latin source. Such a small but telling shift may strengthen the case for comparing the narrative with the troubadour vidas and razos, a genre that was thriving in the mid-thirteenth century, when Tote listoire de France was composed.

The razo is an adjunct to the troubadour vida, a short biography. Both are short narrative texts in Occitan prose, and both are exclusively preserved inside compilations of troubadour poetry. Both vida and razo frame poems by providing them with historicized context and motivation. They embed lyric poetry in the localized biographies of poets and their patrons, and it is likely that they were declaimed alongside troubadour lyric poems. ${ }^{36}$ The genre flourished in Lombardy and the Veneto in the mid-to-late thirteenth century, but its earliest practitioners are troubadours of the thirteenth century, chief among them Uc de Saint-

\footnotetext{
${ }^{34}$ Buridant accepts de Mandach's suggestion that the variant 'post tergum' in one LHF manuscript points to censorship, Buridant, 'La traduction', p.61, n.2, citing Mandach, Chronique, pp.175-6.

${ }^{35}$ McCracken, Romance of Adultery, p.33.

${ }^{36}$ For the razo as a literary genre, see Elizabeth Wilson Poe, From Poetry to Prose in Old Provençal: The Emergence of the "Vidas", the "Razos" and the "Razos de trobar" (Birmingham, Ala.: Summa Publications, 1984), pp.35-66, William E. Burgwinkle, Love for Sale: Materialist Readings of the Troubadour Razo Corpus (New York: Garland, 1997), Lacroix, Les amours du poète, pp.36-41, 49-62, and Simon Pender, 'Vidal in Furs: Lyric Poetry, Narrative, and Masoch(ism)', Comparative Literature, 58. 2 (2006), 95-112.
} 
Circ (fl. c. 1200-49), whose patrons included the Saintongeais nobleman and patron of troubadour poetry, Savaric of Mauléon (d.1233). ${ }^{37}$

Vidas and razos are condensed tales with minimal dialogue, seeking to create a vivid and memorable 'scene'. They share many of the features described by Pizarro: simple, terse prose, minimal description, a tendency to privilege chains of scenes set in strict historical frames over extended causal narratives, and the sparse use of props. ${ }^{38}$ One of the most apposite is the razo that is inserted in the vida of Raimbaut de Vaqueiras (fl. c. 1180-1207). The successful minstrel Raimbaut finds a generous patron in Boniface, Marquis of Montferrat (d.1207), who makes him a knight.

Text:

Don ell s'enamoret de la seror del marqes, qe avia nom na dompna Biatrix, qe fo molher d'Enric del Carret. E troba de lei mantas bonas chansos. Et appellava la "Bel Cavalier". Et per aiso l'apella[va] enaisi, qe a En Rambautz segi aital aventura, qe pozia vezer ma dompna Biatrix qant el volia, sol q'ella fos en sa chambra, per un espiraill ; don neguns no.n s'apercebia.

Et un jor venc lo marqes da cassar; et entret en la chambra et mez la soa spaza a costa d'un leit, et tornet s'en foras. Et ma dompna Biatrix remas en [la] chambra ; et despoillet se son sobrecot et remas en gonnella. Et tollc la spaza et se la ceinz a lie de cavalier. Et tra[i]s la fuor et geta la en alt, et pres la en sa ma et menet se l'al bratz d'una part et d'autra en la spala; et tornet la em fuer, et se la desceinz et tornet la a costa del leit.

\footnotetext{
${ }^{37}$ Burgwinkle, Love for Sale, pp.107-112, Guida, Primi approcci, Léglu, 'Savaric de Mauléon', Cao Carmichael de Baiglie, 'Savary de Mauléon', pp.287-91.

${ }^{38}$ Pizarro, Rhetoric of the Scene, pp.9-14, 41, compare Lacroix, Les amours du poète, pp.4962.
} 
Et En Ranbau[t]z de Vaqera[s] vezia tot so qe vos ai dich per lo spiraill. Don per aso l'apellet pois totas vez "Bel Cavalier" en sas chansos... 39

Translation:

Then he fell in love with the sister of the marquis, who was named Beatrix and was the wife of Enrico del Carretto. He composed many good love songs about her, and he called her Handsome Knight. And the reason for his calling her by that name is this: an adventure befell Raimbaut, because he could look at $\mathrm{Na}$ Beatrix whenever he wished, as long as she was inside her chamber, through a small barred window. It meant that nobody noticed it. One day, the Marquis went out hunting, and he came into the chamber and placed his sword beside a bed, and went back outside. My lady Beatrix stayed inside the chamber, removed her surcote and kept her tunic on. She took the sword and attached round her waist, like a knight. She pulled it out of its scabbard and raised it in the air, then she took it in her hand and she drew it over her arm on one side, and on top of her shoulder on the other. She put it back into the scabbard, unbelted it, and placed it back beside the bed. En Raimbaut saw everything I have told you through the barred window, and because of that he always called her Handsome Knight in his love songs.

[After introducing the song, the razo continues, 'E fo cresut q'elle li volgues ben per amor' (It was thought that she wished him well out of love)].

\footnotetext{
${ }^{39}$ Jean Boutière and A.-H. Schutz, with Irénée-Marie Cluzel, Biographies des Troubadours: Textes provençaux des XIII et XIV ${ }^{e}$ siècles (Paris: Nizet, 1973), LXXb (interpolated version of the vida), pp.451-2.
} 
This razo is an example of condensed but evocative writing on the themes of looking and knowing. ${ }^{40}$ It glosses the senhal by providing a complex erotic drama between its three protagonists, deliberately omitting key information and thereby provoking many questions. Is Beatrix aware that Raimbaut regularly spies on her in her chamber, 'sa chambra'? If she does, then her gestures are meant for him. If she does not, then the lover is intruding on gestures that are purely meant for her gratification. Each option offers a potential narrative effect. One is predicated on the admiration for the lady's cunning. The other makes her the unwitting participant in a voyeuristic game between the poet and his audience. How, then, does Raimbaut's senhal work for Beatrix? Does it try to signal in his songs that he has gained secret knowledge about his lady, or is it a coded gesture of love that only she can understand? The audience believe thereafter that Beatrix merely 'wished him well out of love'. There is no hint of a scandal.

Moving beyond narrative effect to the protagonists' motivation, does Beatrix's selfknighting have anything to do with the fact that Raimbaut has just been knighted by her brother? A further twist in this subtle vignette lies in the identity of the sword's true owner. The razo names him as 'lo marqes', who must therefore correspond to Beatrix's brother, the 'marques Bonifaci', and not to her husband. Why, then, does her brother (the marquis) leave his sword in his sister's chamber, a room that contains more than one bed (he leaves the sword 'a costa d'un leit', beside $a$ bed, not the bed), but where she can strip and play with a sword and scabbard without risking discovery? Readers might surmise that the scenario played out by Beatrix reflects any of a number of possibilities: a childlike game played out between brother and sister; the consequence of the marquis sharing a joke with her concerning Raimbaut's recent knighting at his hands; two men bonding over a joke in which

\footnotetext{
${ }^{40}$ Burgwinkle, Love for Sale, pp.189-90, 252-56. A.C. Spearing, The Medieval Poet as Voyeur: Looking and Listening in Medieval Love-Narratives (Cambridge: Cambridge university Press, 1993), pp.1-22.
} 
the woman is placed in the role of passive, observed victim (as Burgwinkle suggests, 'she is the place at which the male desires intersect'). ${ }^{41}$ The first and second possible interpretations accord Beatrix the agency that she deploys in this tale, and make Raimbaut the victim of the bonding strategies between brother and sister, who are both his patrons. If there are several beds in the chamber and the sword is originally placed beside one of them, the scene is intimate and voyeuristic, but not adulterous. Beatrix's appropriation of the sword, the key emblem of masculine power and prestige, is twofold. First she belittles it by strapping it to her undressed (and therefore visibly female) body, then brandishing the sword in the air, a gesture possible only for an experienced and strong warrior - or a minstrel. Next, she performs her own version of the marquis's dubbing ceremony on herself. Whatever she is doing, it does not involve rejecting her husband's authority, as she is neither in his bedchamber nor in his presence. Arguably, she is both emulating and enacting the marquis's love for Raimbaut, conflating male and female patrons. Beatrix is mute but eloquent in the razo. Her secret gestures are not glossed by her own words. Rather, Raimbaut designates her as Bel Cavalier forever afterwards as the only verbal, public expression that is permissible for their complex drama. ${ }^{42}$

Returning to Tote listoire, both tales stage an erotic scene enacted when a woman thinks that she is alone because the male authority figure (her husband the king, her brother the marquis) is out hunting. Both stage the unexpected return and then departure of that third party. Both focus the erotic drama on gestures that are shared by lovers inside the intimate but not necessarily private space of the woman's chamber. In both, the lover is absent from the scene: Raimbaut is looking into the room in secret, and Landeric is not there. The royal couple's chamber, where Fredegund washes her hair and can expect both her husband and her

\footnotetext{
${ }^{41}$ Burgwinkle, Love for Sale, p.190.

${ }^{42}$ Burgwinkle, Love for Sale, pp.252-6.
} 
lover to enter unannounced, is borrowed from the Latin text in the LHF, 'in camera palacii'. Beatrix and her brother appear to share a similar open-yet-intimate space that is characterized by its notional invisibility to prying eyes. In both stories, a woman's secret is revealed within her allotted intimate space within a household. ${ }^{43}$

In both narratives, the woman's body receives the symbolic touch of an object. Beatrix uses the familiar movements of the ritual of dubbing a knight, by presenting herself dressed only in a tunic to have the sword belt and scabbard strapped to her waist. She enacts her brother's gestures as well as Raimbaut's, in that she both gives and puts on the sword and scabbard, and then she both inflicts and receives the blows of the sword on her shoulders. More opaquely, Fredegund feels the blow of a stick on her buttocks (or shoulders) while she has her head down, and assumes that it is a gesture performed by her lover Landeric, when the stick is in fact wielded by her husband, who is said to love her deeply ('cum amaret eam nimis'):

...illa caput suum abluens aqua in ipsa camara, rex vero retro veniens, eam in natibus suis de fuste percussit. At illa cogitans, quod Landericus esset, ait: "Quae sic facis, Landerice?" Respiciens sursum viditque, quod rex esset; expavit vehementer. Rex vero nimis tristis effectus, in ipsa venatione perrexit (Krusch, pp.302-03)

...As she was washing her hair with water inside her own chamber, the king (coming back) hit her on the buttocks with a stick. Thinking that this was Landeric, she said: "Why are you

\footnotetext{
${ }^{43}$ On the ambivalence of private space, see Spearing, Medieval Poet, pp.17-19, Otis-Cour, "“De jure novo"”, pp.351-2.
} 
doing that, Landeric?" Looking up and seeing that it was the king, she was terrified. The king, deeply saddened by this, returned to his hunt.

When she feels the blow of the stick, Fredegund betrays her secret by crying out, 'Porque faiz tu co Landeric ?' The narrative, once more, is concise. Her use of the familiar second-person address $t u$, and the informality of the question, both signal that she is not speaking to Landeric as a queen speaks to a palace official. Only her reaction is given, not the king's. She looks up ('reguardans sus'), recognizes her husband, and she feels fear. In this instance, she is not 'the place where the male desires intersect', as Burgwinkle described Beatrix. Far from it, as it appears to be her own desire that is inadvertently intersecting with her husband's. The narrator works in miniature once more by keeping the information about the king's sadness to the following sentence, when he is on the hunt: 'Li reis molt tristes ala chaicer'. The Latin source is identical: the king returns home because he loves his wife and sets back off on his hunt with unspoken sadness in his heart: 'Rex vero nimis tristis effectus, in ipsa venatione perrexit.' Neither the Latin text nor the translation offer any explanation for the king's gesture, nor for why she should assume that it is the work of her lover.

Pizarro argues that Chilperic, dressed for the hunt, is 'using his whip hand' in the sense that he strikes Fredegund as if she were a horse, to symbolize that he is at once her master and her husband. He suggests also that Chilperic's blow 'may even be a pledge of future punishment for infidelity' ${ }^{44}$ However, neither of Pizarro's glosses on the text, which rely on the assumption that Chilperic is jealous and violent, fits the spare but informative narratorial interventions concerning the king's feelings of love and sadness. A modern reader would supply the assumption that Fredegund's slip of the tongue imposes a legal obligation

${ }^{44}$ Pizarro, Rhetoric of the Scene, p.14. 
of violent retribution on her husband, but Otis-Cour's research would advise caution in this respect, all the more so in the thirteenth-century context of the translation. ${ }^{45}$ There are therefore significant gaps in the text, where motives and causal relationships must be furnished by the reader. In turn, Pizarro suggests that this is an identifiable narrative device, exploited primarily by Gregory of Tours, whose work is the source of the LHF. ${ }^{46}$

The same concision is strengthened in the translated dialogue between Fredegund and Landeric, where several details are omitted:

Si li dist : "Pensa que feras, quar demain serom liure a torment." Il dist enplorant, "Ie no sai que ie fazce." Ela li dist, "N'aies paor. Oies mon conseil e no murrom..." (fr. 5714)

She said to him, "Think of something to do, because tomorrow we will be given over to be tortured." He said, weeping, "I do not know what to do." She said, "Do not be afraid. Listen to my advice and we shall not die."

The LHF is more flattering to Landeric, who enters the narrative as 'vir ingeniosus ac utilis', a clever and helpful man (Krusch, p.302). His reaction is both more complex and more informative:

Fredegundia itaque vocavit ad se Landericum et enarravit haec omnia, quae rex fecerat, dicens : "Cogita, quid agere debeas, quia crastina die ad tormenta valida exibimur." Et ait

${ }^{45}$ Schenk, 'Reflections', pp.26-27. Otis-Cour, “"De jure novo”, p.363.

${ }^{46}$ Pizarro, Rhetoric of the Scene, pp.34-35, 41-42. 
Landericus, contritu spiritu, commotus lacrimis, dicens: "Tam mala hora te viderunt oculi mei! Ignoro enim, quid agere debeam, quia compremunt me undique angustiae. "Et illa dixit ei : "Noli timere, audi consilium meum..." (Krusch, p.303)

Fredegund summoned Landeric to her and told him everything that the king had done, saying: "Think about what you can do, because we shall be handed over to be tortured tomorrow." Landeric said, contrite in spirit and overcome with tears, saying : "An evil hour it was when my eyes first saw you ! I do not know what to do, because my fears and anxieties are oppressing me." And she said to him, "Do not be afraid, listen to my advice..."

The translation preserves Fredegund's insinuation that Chilperic will have the couple tortured (rather than either questioned or killed). Once again, the effect is both abrupt and rich in connotations. Her request for some suggestions in the imperative ('Pensa...') is met by Landeric's terrified admission that he cannot think of anything: the verb far (to do) moves from 'que feras' to the subjunctive ('...que ie fazce'). She then comforts him, once more in the imperative: 'N'aies paor', and proposes her own solution. Two particularly effective details lie in the use of the single adjective enplorant (weeping) to describe Landeric's emotional reaction, omitting the Latin text's depiction of a man who is contrite ('contritu spiritu, commotus lacrimis') and who bitterly regrets having embarked on an affair with the queen. Legally speaking, the LHF exonerates Landeric by demonstrating his contrition, whereas Tote listoire does not. In the translation, Fredegund's lover is neither helpful, clever, nor contrite. He also acquires the office of mayor of the palace after the murder, whereas in the Latin, he is already the most powerful royal official. Thus in the translation, Landeric is the queen's creature rather than her equal. 
The vernacular translation plays on its miniaturising tendencies in order to produce a well-crafted, well-framed anecdote. It displays the same sparing use of mise-en-scène, psychological motivation, and props as in the troubadour razo, in order to produce a similar effect of condensed emotional intensity. As with the razo, it raises more questions than it can answer, all the better to provoke meaningful debate among its listeners. It also offers condensed narrative in prose, it sets a vivid, erotic tale within an explicit historical frame, and it provides no moralising gloss. The introduction of a pair of minstrels as the queen's henchmen is particularly evocative of troubadour poetry.

Tote listoire was composed in a learned, courtly milieu, in a geographical and linguistic region associated with the earliest known practitioner of troubadour narratives. This and the other observations above suggest that Tote listoire de France forms part of the reception of Latin historical writings within a cultural context that also informed Occitan lyric poetry and its narrative offshoots. It coincides with the rise of prose historiography in French via this earliest $P s$-Turpin translation, which assures its reader in its prologue that 'nus contes rimes n'est verais' (no rhymed tale is true) (fr. 124, fol.1). ${ }^{47}$ It is likely that the adventures of an ingenious domna in a remote pre-Capetian past would have found a sympathetic audience on the borders of the Capetian and Plantagenet crowns, but above all, this translation sits on the cusp of divergent literary traditions at their moment of birth.

\footnotetext{
${ }^{47}$ Buridant, 'La traduction', p.114. Teresa Shawcross, The Chronicle of Morea : Historiography in Crusader Greece (New York: Oxford University Press, 2009), p.164.
} 